\title{
Planning the optimal solution for wastewater management in rural areas - case study
}

\author{
Joanna Boguniewicz-Zablocka ${ }^{1 *}$, Iwona Klosok-Bazan ${ }^{1}$, Andrea G. Capodaglio ${ }^{2}$, \\ and Joanna Ploskonka ${ }^{1}$ \\ ${ }^{1}$ OUTech, Politechnika Opolska, 45-271 Opole, Poland \\ ${ }^{2}$ UNIPV, Universita degli Studi di Pavia, Engineering Department, 27100Pavia, Italy
}

\begin{abstract}
Water management and associated wastewater management is an inseparable element of life and development of modern societies. Collection and treatment of wastewater has a significant impact on the environment and economy, both at the local and global level. It is therefore necessary to proceed to activities that ensure proper wastewater management, especially in rural and low-density areas, where it is necessary to search for optimal solutions with regard to sewage systems, including wastewater treatment plants. One of the solution for wastewater treatment from houses without access to sewerage collection system is the construction of on-site wastewater treatment plants. Construction of on-site wastewater treatment plant poses a number of challenges for municipalities and potential investors and has been discussed by many. Aim of this paper is to draw the current status and perspectives of on-site wastewater treatment systems in Poland, with focus on selected case study from rural areas. The paper presents a way to solve the problem of wastewater management in the municipality of Pietrowice Wielkie using local biological wastewater treatment plants. The article presents technological, technical and economical aspects of the above-mentioned solutions and analysis of the advantages and disadvantages of the system proposed by the municipality.
\end{abstract}

\section{Introduction}

Increasing environmental awareness, life quality and legal requirements resulting from both Polish and European regulations regarding the quality of sewage discharged, has caused that the problem of wastewater management became extremely important, starting from the municipal level and ending at the voivodship. One of the basic tasks of the commune is to solve the problem of wastewater management. This is particularly important in rural areas without a central drainage system. Polish regulation on collective water supply and collective sewage disposal [1] places high demands on municipalities. Proper wastewater management in rural areas may be a problem, mainly due to the significant dispersion of buildings, which forces the construction of long sewerage pipes. The high cost of building a sanitary and rainwater sewerage system and sewage treatment plants with under-financing of municipalities is often a project that exceeds their financial capabilities. Therefore, in areas where construction of a centralized sewage collection system is not considered 
economically viable, decentralization is becoming quite popular [2]. In this contex, a significant number of municipalities do not make efforts to build or extend sewerage systems, hence the sewage management is primarily carried out on septic tanks and small household sewage treatment plants. An alternative is to obtain funding for projects related to water and sewage management, whether from EU funds or the National Fund for Environmental Protection and Water Management.

Futhermore, the end result, regardless of the chosen method of treatment and disposal of sewage is to reduce its negative impact on the environment, so that it does not pose a threat to human and animal life and health.

Nevertheless, there are very few properly operating local or individual sewage systems in our country [3].The most widespread are septic tanks, theoretically sealed, and practically the leakiest septic tanks, from which sewage is transported by tank vehicle to the treatment plant and sometimes in an uncontrolled way it results in the environment. The household sewage treatment plants with the discharge of treated sewage to the ground are an effective and safe solution, provided that they are properly designed, constructed and operated [4]. Considering that, initiatives at the household level depend very much on the urgency and gravity of the issue and the level of awareness of the people involved [5].

The subject of the paper is to present the possibilities of solving the problem of wastewater management in rural areas, together with the presentation of the method of wastewater treatment in the commune of Pietrowice Wielkie using the so-called domestic biological sewage treatment plants (DBSTP) and the analysis of the advantages and disadvantages of the system proposed by the municipality. The aim of this work is to present and analyze the effectiveness of the applied wastewater treatment system in the municipality. The work covered the entire area of the municipality of Pietrowice Wielkie.

\section{Materials and methods}

\subsection{Case study area description}

According to the data obtained on the website of the Central Statistical Office[6], the commune of Pietrowice Wielkie (Code: 2244911072) is located in the Śląskie Voivodeship, subregion 49 - Rybnik, Racibórz district. The commune consists of 11 towns. The Pietrowice Wielkie commune is located in the Odra River basin, in the Psina River basin (the catchment area covers $559.9 \mathrm{~km}^{2}$, and its total length is $49.3 \mathrm{~km}$ ), within three underground water reservoirs [7,8] Main Underground Water Reservoir (GZWP) No. 332 "Subniecka kędzierzyńsko - głubczycka", the Quaternary Utility Groundwater Level QI of the Upper Oder Region, the Trench Terrestrial Underground Water Level TrI Kuźnia Raciborska.

Wastewater management implemented in the Pietrowice Wielkie commune until the implementation of the construction program for domestic sewage treatment plants (DSTP) was based on septic tanks, located on the residential property. Very often the tanks were old devices with questionable leak-tight containment structure. These small-scale units have high relevance in low population-density areas, where discharge of sewage to a central wastewater treatment plant (WWTP) through a central drainage system is not economically feasible [3].

In addition, the municipality was concerned about the various forms of transportation of the collected wastewater. Leaving the functioning of such sewage management unchanged was unacceptable in terms of both Polish and European Community applicable law requirements but mostly in terms of ensuring the safety of the environment, and especially protection of the two most vulnerable elements: water and soil. 
The aim of the Pietrowice Wielkie commune was to provide the residents with individual wastewater treatment systems, certified in accordance with the harmonized European standard EN 12566-3: 2005 + A1: 2009; replaced by PN-EN 12566-3 + A2: 2013 [9] for a specific series of devices issued by a laboratory notified by the European Commission. Along with the assembly of the DSTP, accompanying devices were also made, i.e. an absorbent well and electrical installation. The installation of approx. 1170 pcs. DSTP allow to clean $511.74 \mathrm{~m}^{3}$ wastewater per day [10].

\subsection{The formal and legal basis for the functioning of the DSTP}

In accordance with the Act of 20 July 2017 Water Law [11] distinguishes three types of water use: general, ordinary or special. Article 35 additionaly lists so called water services. This division is extremely important from the point of view of formal and legal requirements for the operation of the DSTP. Most wastewater treatment plants were made as part of normal water use, i.e. they were made for the family, in the area where this family is owner, and the amount of wastewater discharged not exceeding $5 \mathrm{~m}^{3}$ per day. At the above-mentioned Municipality, Pietrowice Wielkie did not have to obtain water-law permits. The water-law permit is required only in the case of household installed sewage treatment plants, some instances of public utility buildings and when the discharge of treated sewage exceeds the boundaries of the real estate to which the entity had a legal title. The commune received 49 decisions granting a water permit for special use of water and the construction of a water device in the form of an absorption well.

The legal basis enabling the use of household wastewater treatment plants is provided in art. 83 section 4 of the Act on Water Law, quoted above: "In places where the construction of collective sewage systems would not bring environmental benefits or would result in excessive costs, it is necessary to use individual systems or other solutions that ensure the same level of environmental protection as collective sewage systems". In addition, pursuant to art. 5 section 1 point 2 of the Act of 13 September 1996 on maintaining cleanliness and order in municipalities [12] the legislator is imposing on the owner of real estate located in a given municipality the obligation to connect the property to an existing sewerage system. In the case where the construction of a sewage system is technically or economically unjustified, it should be equipped with a holding tank or a domestic sewage treatment plant, fulfilling the requirements specified in separate regulations. In the quoted article there is included a derogation: considering the case when the property is equipped with a domestic sewage treatment plant that meets the requirements specified in separate regulations (ie it treats sewage to parameters acceptable under separate regulations), then the connection of this property to the sewage system is not obligatory. Sites where DSTP are located are covered by local spatial development plans i.e. local laws in which there is no direct prohibition on locating such investments in this area $[13,14]$.

\subsection{Principles of operation of domestic sewage treatment plant}

According to the information obtained on the website of the producer of individual INNOCLEAN ${ }^{\circledR}$ wastewater treatment plants [15], they operate on the Sequencing Batch Reactor (SBR) principle. In the first chamber of the sewage treatment plant (initial settling tank) there is a mechanical cleaning process, during which, using flotation and sedimentation processes, solids contained in sewage from liquid parts are separated. Solid parts falling to the bottom form a sediment. In the first chamber there is also the first phase of disintegration of organic compounds contained in the domestic wastewater, i.e. ammonification. The sewage from the preliminary settler, after reaching a certain level is 
pumped into the chamber of the activated sludge, where the main phase of the biological treatment process is running. Wastewater is subjected to short impact aeration phases, resulting in partial denitrification. The purification phase lasts 6 hours. During this phase, purification is carried out by microorganisms. The use of the air-raising system guarantees mixing of the sludge, which is one of the necessary factors for the proper course of the process in the activated sludge chamber. Subsequently a deposition phase takes place, which lasts 2 hours. The treated wastewater that has been collected in the upper part of the chamber is pumped out. The cycle ends after 8 hours. If new sewage accumulates over the past eight hours, the cycle starts anew, if not, or a small number of sewerage will flow - the device switches to energy saving mode. The remaining unnecessary activated sludge recedes to the primary settling tank. The unquestionable advantage of this generation of INNO-CLEAN ${ }^{\circledR}$ treatment plants is the option of maintaining conditions appropriate for the survival of activated sludge during long-term interruptions in the supply of raw sewage [16].

\section{Results and discussion}

\subsection{Choosing a sewage disposal system}

The municipality of Pietrowice Wielkie has decided to provide the residents with local treatment plant instead of building a sanitary sewage system. The decision was made after conducting an economic and technical analysis of both options for discharging treated wastewater. The argument for choosing the DSTP was the specific dispersed character of the commune and the estimated cost of construction and operation of the sanitary network (about $90 \mathrm{~km}$ ) along with the sewage treatment plant. The economic analysis was as follows [17]:

I. construction and operation of sewage network and sewage treatment plants:

- the cost of construction of a $90 \mathrm{~km}$ sanitary sewage system with the average price for 1

$\mathrm{m}$ of sewage system at the level of 500 PLN: 45,000,000 PLN

- the cost of constructing a sewage treatment plant: 6,000,000 PLN

- the cost of $1 \mathrm{~m}^{3}$ of sewage, calculated on the basis of research documentation performed by the Department of Water Protection

- Main Institute of Mining in Katowice: on the day of preparing the documentation would be at the level of $17.33 \mathrm{PLN} / \mathrm{m}^{3}$

II. construction and operation of the DSTP:

-the cost of the construction program for 1,200 household sewage treatment plants (purchase of the device with absorption well - 20,000 PLN/1DSTP): 24000000 PLN -monthly cost of maintaining the propoer operation of 1DSTP : 15-20 PLN

Before applying to the National Fund for Environmental Protection and Water Management (NFEPWM) for funds to implement the project, the Municipality of Pietrowice Wielkie collected the residents' declarations of willingness to participate in the Municipal Wastewater Treatment Plant [17] in order to evaluate the expected amount of needed wastewater treatment plant (adapted to the needs of individual households). With each of the participants joining the program, there was a land use agreement signed, together with a declaration of participation in the program, ensuring the costs related to the maintenance of the sewage treatment plant and a declaration of financial participation. Each of the participants joining the program was obliged to pay an installation cost of DSTP in the amount of 1,845 PLN and to pay monthly fixed fees in the amount of 24 PLN net plus the applicable VAT rate (with the possibility of increasing the fee, but no more than once a 
year). The amount was not higher than that resulting from the price index of consumer goods and services announced by the President of the Central Statistical Office for the previous year. The owner of the DSTP installed on the lands of the DSTP is the Municipality of Pietrowice Wielkie. The person joining the program does not acquire ownership of the installed treatment plant.

With regard to the above, the Ordinance of the Head of the Municipality of Pietrowice Wielkie introduced the Program for the construction of domestic biological sewage treatment plants for the Municipality of Pietrowice Wielkie. As a result of provided analysis and successful program financing the municipality of Pietrowice Wielkie has provided the residents with local treatment plant. Table 1 presents a cumulative list of the quantities and types of household sewage treatment plants installed.

Table 1. List of the number and types of DSTP mounted

\begin{tabular}{|c|c|c|c|c|c|c|c|c|c|c|}
\hline \multirow[b]{2}{*}{$\begin{array}{c}\text { Types of } \\
\text { DSTP }\end{array}$} & \multicolumn{10}{|c|}{ Number of DSTP mounted in a given area [items] } \\
\hline & 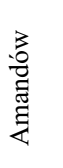 & 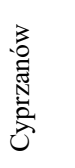 & 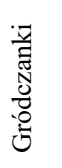 & 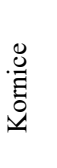 & 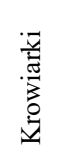 & 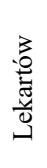 & $\begin{array}{l}\frac{3}{0} \\
\frac{0}{a} \\
\sum\end{array}$ & 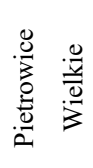 &  & 离 \\
\hline $\mathrm{EW}^{*} 4 / 6$ & 19 & 105 & 25 & 64 & 127 & 40 & 125 & 453 & 149 & 125 \\
\hline EW 8/10 & 0 & 2 & 2 & 1 & 7 & 1 & 2 & 14 & 0 & 2 \\
\hline EW 12 & 0 & 0 & 1 & 0 & 1 & 0 & 1 & 2 & 0 & 1 \\
\hline EW 14/16 & 0 & 0 & 0 & 0 & 0 & 0 & 0 & 0 & 1 & 0 \\
\hline EW $18 / 20$ & 0 & 0 & 0 & 0 & 1 & 0 & 0 & 3 & 1 & 0 \\
\hline EW 44 & 0 & 0 & 0 & 0 & 2 & 0 & 0 & 1 & 0 & 0 \\
\hline Total: & 19 & 107 & 28 & 65 & 138 & 41 & 128 & 473 & 151 & 128 \\
\hline
\end{tabular}

*EW reffer to types of DSTP from INNO-CLEAN company

\subsection{Required degree of wastewater treatment}

The degree of treatment of domestic sewage that can be discharged into the environment (in the case of the Municipality of Pietrowice Wielkie, the receiver for sewage is ground) is regulated by the ordinance of the Minister of Environment of November 18, 2014 on conditions to be met when discharging sewage into waters or into the ground, and on substances particularly harmful to the aquatic environment [18]. Conditions imposed by the regulation depends on whether the commune creates the agglomeration or not and on the value of the people equivalent (P.E.) The municipality of Pietrowice Wielkie does not create an agglomeration defined as an area where the population or economic activity is sufficiently concentrated. Therefore the municipal sewage does not need to be collected and treated centrally in WWTP [11].

Required concentrations of pollutants in treated wastewater discharged cannot be higher than the maximum concentrations for treatment plants serving less than 2,000 P.E. and are at the level of: $\mathrm{BOD}_{5}<40 \mathrm{mg} / 1, \mathrm{COD}<150 \mathrm{mg} / 1$, suspended solids $<50 \mathrm{mg} / 1$. According to the manufacturer's data, the INNO-CLEAN wastewater treatment plant (based on tests carried out by the European Union notified Laboratory - MFPA Wiemar) guarantees a $\mathrm{BOD}_{5}$ reduction of $98 \%$, COD up to $92 \%$ and suspended solids of $94.1 \%$.

In addition, discharging to the ground (within the land that is the owned property) sewage from own household is also conditioned by the amount of treated sewage discharged (up to $5 \mathrm{~m}^{3}$ / day) and separation of the sewage effluent into the ground with a 
layer of soil with a thickness of at least $1.5 \mathrm{~m}$ from the highest usable aquifer level of groundwater. In order to verify the fulfillment of the condition regarding the distance from the highest usable aquifer level of groundwater, the Municipality of Pietrowice Wielkie commissioned a hydrogeological expert report describing soil and water conditions on plots designated for the development of DSTP. As per the developed documentation - the depth of the first water-bearing level on the test area is $17 \mathrm{~m}$ a.s.l.

The amount of sewage discharged is verified by Municipal Services Department w Pietrowicach Wielkich based on the water meters installed at the connection of the water supply network to individual buildings.

\subsection{Wastewater monitoring and service}

By submitting an application to the National Fund for Environmental Protection and Water Management (NFEPWM) for co-financing, the Municipality of Pietrowice Wielkie declared achieving the following values of indicators: BOD5 $<40 \mathrm{mg} / 1$, COD $<150 \mathrm{mg} / 1$ and total suspended solids TSS $<50 \mathrm{mg} / 1$. The number of samples of treated domestic sewage cannot be lower than 4 samples per year (for P.E. less than 2000), and if it is shown that the sewage meets the required conditions - 2 samples in the following year. In order to confirm the achievement of the ecological effect, the Municipality was obliged to deliver to NFEPWM 117 analyzes of collected samples of treated wastewater. The analysis of the samples was done based on those test results. In order to illustrate the obtained values a graph was made on which the average and maximum value for a given type of EW DSTP plant was presented (Figure 1). In the drawings, the limit values of the indices in the red and black line are marked. The analysis of the test results did not reveal any exceedances of the admissible values of the determined indices.

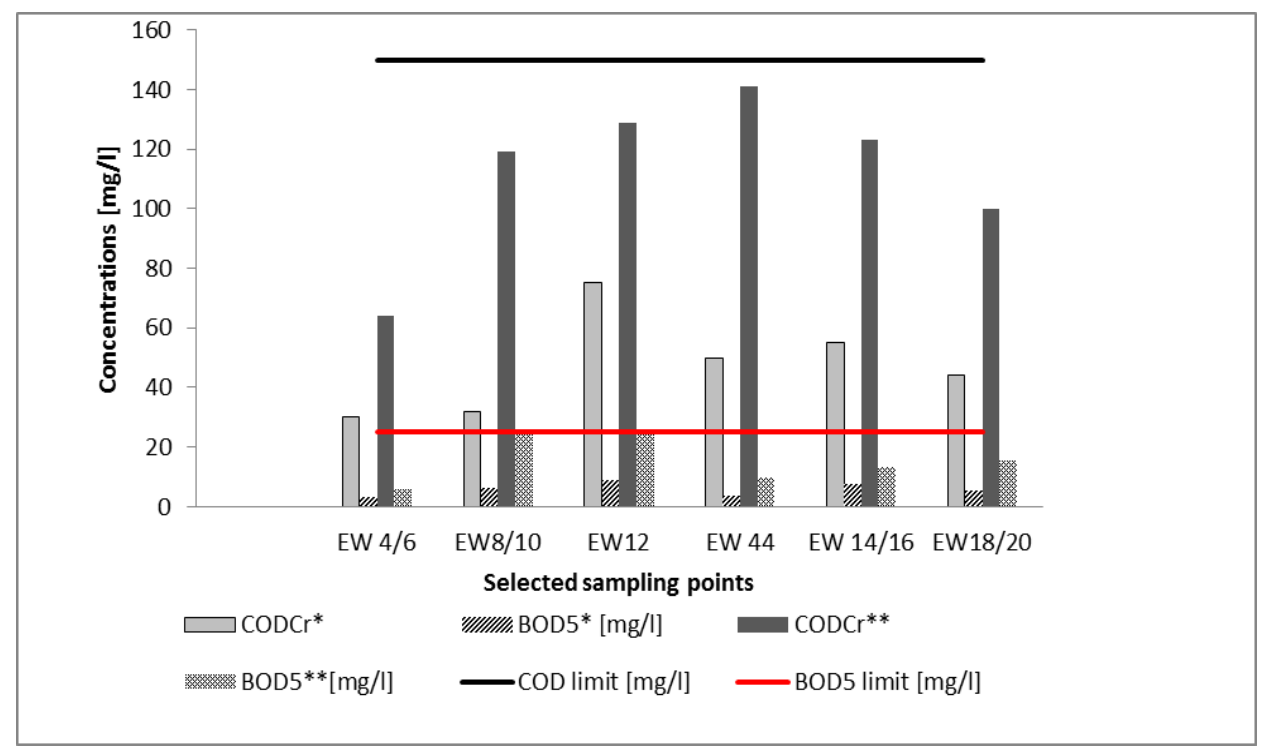

Fig. 1. The results of analysis of treated wastewater

Analyzing the results of sewage samples presented above, it can be noticed that the limit values set out in the applicable legal regulations have not been exceeded. However, some of the points were dangerously close to reaching the limit values. This may be due to the fact that the activated sludge has not yet developed/growth enough, however, the so-called human factor cannot be overlooked. 
Operation of a DSTP does not require any special knowledge or experience from the user. However, DSTP are governed by certain operational regimes, which cannot be forgotten. It should be remembered that biomass is responsible for treating wastewater and that is why it is important to care of its stability and vitality. The importance of user habits was also strongly emphasized in many publications dedicated to household wastewater treatment plants $[2,3,4,23]$. Therefore, it is forbidden to discharge: disinfectants, medicines, fats, food oils and solvents into the sewage system. Throwing solid waste into the sewage system (such as tissues, paper towels, cigarette butts, etc.) can plug the sewer pipes as well as elements of the sewage treatment plant itself.

\subsection{The management of sewage sludge from DSTP}

As a result of the functioning of sewage treatment plants is the formation of sewage sludge, which requires disposal and utilization. Estimated amount of sediments formed for 1170 DSTP - was specified in the NFEPWM application for co-financing [10] at the level of $27,155.6 \mathrm{~m}^{3}$ / year. According to information obtained from the Head of the Pietrowice Wielkie commune [17], sewage sludge from treatment plants is collected by the employees of Municipal Services Department (MSD) in Pietrowice Wielkie and the company HYDROKAN Kietrz. In the case of MSD, the service is provided by means of a slurry tanker: IVECO with a capacity of approx. 4,000 1 and so-called "barrel" with capacity 2,500 1. Sewage sludge is transported to the catchment station of the Sewage Treatment Plant in Krzanowice and the Sewage Treatment Plant in Kietrz.

According to the instructions for the user, the producer of the household sewage treatment plant recommends emptying the settler as soon as the sludge level reaches $1.0 \mathrm{~m}$. It is customarily assumed that the slurry tank (having the appropriate permit for the transport of liquid waste) receives sewage sludge once a year, although the individual habits of the treatment plant users (e.g. the amount of toilet paper used) also have an impact on the amount of generated sediment [19].

It should be noted that the handling of sewage sludge arising during the operation of the DSTP is the same as with liquid waste contained in a free standing septic tank (so-called cesspools), which also require periodic emptying [20]. One thing is that the actual amount of pollution in sediments from household treatment plants is several dozen times greater than in the case of cesspools. Table 2 lists the pollutant concentrations of both liquid waste groups [21].

Table 2. Comparison of pollutant concentration based on [21]

\begin{tabular}{|c|c|c|c|c|}
\hline \multirow{2}{*}{$\begin{array}{c}\text { Pollutant } \\
\text { indicators }\end{array}$} & \multicolumn{2}{|c|}{ Wastewater from septic tank } & \multicolumn{2}{c|}{ Sewage sludge from DSTP } \\
\cline { 2 - 5 } & mean & range & mean & range \\
\hline $\mathrm{BOD}_{5}\left[\mathrm{~g} / \mathrm{m}^{3}\right]$ & 1500 & $600-5000$ & 45000 & $40000-100000$ \\
\hline $\mathrm{TSS}\left[\mathrm{g} / \mathrm{m}^{3}\right]$ & 2500 & $2000-5000$ & 66000 & $50000-100000$ \\
\hline
\end{tabular}

The above list shows how large pollutants loads must be faced by the Sewage Treatment Plants receiving sediments from the DSTP. Unlimited discharges of such heavily loaded liquid waste can cause serious disturbances in the technology adopted on a given treatment plant, and therefore it generates high costs of further operation (e.g. costs of modification of installations and technologies, or costs of increased fees for introducing insufficiently treated wastewater from DSTP for the environment, that could happened during failure). 


\section{Conclusions and remarks}

The Pietrowice Wielkie commune, after conducting analysis, taking into account the specificity of scattered urban development existing in its area, and after comparing the costs of construction and use of an alternative form of wastewater treatment (WWT) and the costs of building a sanitary sewage network together with a sewage treatment plant, selected a variant using individual treatment systems wastewater. Within the territory of the Pietrowice Wielkie commune, 1,170 pieces of household sewage treatment plants DSTP were installed with the assistance of NFEPWM, in which more than $511.56 \mathrm{~m}^{3}$ of sewage are treated per day (in total, DSTP is in the commune over 1,300 pcs.). After cleaning, the sewage is discharged through the absorbent wells into the ground.

The commune decided to use INNO-CLEAN domestic wastewater treatment plants from a wide range of devices. Economic and environmental considerations (terrain shape) were in favor of choosing this model. In addition, the assembly costs and monthly use were considered when selecting the system. It is still necessary to take into account the costs of long-term operation, repairs, costs of replacing worn components and those of sewage sludge export. At this point, it should be noted that some existing sewage treatment plants are not adapted to the treatment of sewage sludge, and the technologies used cannot cope with such heavy pollution loads that sewage sludge from DSTP brings. In connection with the above, one can expect restrictions in the acceptance of sewage sludge for the stations of the sewage treatment plant located in the nearest area of the commune, and this will increase the cost of sewage sludge transport to further located sewage treatment plants. In addition, the payment for collected sewage sludge is based on their pollution load. If the sludge will have unfavorable parameters (exceeded pollution values), additional fees may be charged for their acceptance into the WWTP station. In addition, the municipality is obliged to pay fees for using the environment for discharged wastewater.

The costs of testing sewage discharge samples cannot be omitted. However, the cost of analyzing one sample - in the case of sewage treatment plants it is considerably lower than the analysis of 1,360 samples from the DSTP. As per the above, it may turn out after 20-30 years of operation that the selected system based on DSTP did not prove to be a cheaper solution than the construction of sewage system and traditional sewage treatment plant. Particularly because the entire service cost is covered by municipality founds [3,4].

It should also be mentioned that the task of the commune as a responsible unit, among others for wastewater management, cannot focus only on one type of wastewater. By solving the problem of managing domestic sewage with the help of DSTP (without foreseeing, for example, the construction of sewage treatment plants). Industry entities are forced, to look for other ways to manage wastewater which is created by them. If wastewater are biologically degradable (eg. from dairy industry) appropriate type of technology to treat them could solve the problem [22]. Treated industrial wastewater as opposed to the wastewater biologically degradable to the ground cannot be introduced. Alternatively, it can be discharged into waters, or collected in an airtight container and transported to a sewage treatment plant.

In addition, it should be noted that it is easier to exercise permanent supervision over one "pipe end" than over a system consisting of more than 1,000 discharging points. It is significant, because in the case of the $\mathrm{BOD}_{5}, \mathrm{COD}$ and TSS when measured concentration in the effluent is exceeding the permissible values, the commune is obliged to pay an increased fee for using the environment.

To sum up, as of the date of this work, knowing that this system operates in the municipality of Pietrowice Wielkie approximately 3 years, it can be concluded that the problem of sewage management has been partially solved. This is not an ideal system, and 
whether it is cheaper than a system based on a sewage system and a collective sewage treatment plant, it will be possible to determine it after several years of operation. An important role will be played by the monitoring of both the correct operation of the DSTP as well as the preventive monitoring of water quality in the groundwater intakes. Nevertheless, the solution to the sewage management problem applied by the Pietrowice Wielkie commune can be considered unique in the country-wide scale.

\section{References}

1. Regulation (PL) no 2180/2017 of the Minister of the Environment of Poland about water supply and wastewater discharging. JoL No 2180.(2017)

2. A.G. Capodaglio, A. Callegari, D. Cecconet, D. Molognoni, Water Practice and Technol. 12, 2, pp 463-477 (2017)

3. J. Boguniewicz-Zablocka, A.G. Capodaglio, Economic and Environmental Studies 17, 4 (44/2017), pp1103-1119 (2017)

4. A.G. Capodaglio, Resources 6, 2/22 (2017)

5. A.G. Capodaglio, P. Ghilardi, J. Boguniewicz-Zablocka. Water Practice and Technol. 11, 1, pp 176-186 (2016)

6. Central Statistical Office (2014) for information about the devices and municipal services in the field of sewage. Access 16 September 2017. http://stat.gov.pl/bdl/app/slow_msc =Pietrowice+Wielkiep_czas=20\#)

7. Architectural and urban planning studio by Lucjan Knura. Forecast of the impact of the local spatial development plan on the environment in municipality Pietrowice Wielkie. Racibórz (2015)

8. A.S. Kleczkowski. Map of main aquifiers of underground water (GZWP), AGH, Kraków (1990).

9. Polish norms no PN-EN 12566-3+A1, Small treatment plants for P.E. 50. Part 3, PKN, Warszawa (2009)

10. Application form for funding project entitled "Przydomowe Biologiczne Oczyszczalnie Ścieków dla mieszkańców Gminy Pietrowice Wielkie sposobem na ochronę środowiska naturalnego". National Fund for Environmental Protection and Water Management (2014)

11. Regulation (PL) No 1566/2017 of the Minister of Environment on water law. Official Journal No 1566. Warsaw (2017)

12. Regulation (PL) No 132/1996 about maintaining cleanliness and order in municipalities (1996)

13. Resolution No XXV/282/2009 of the Municipality Council Pietrowice Wielkie from 17 June 2009 about local development plan in Pietrowice Wielkie.

14. Resolution No XXIV/260/2009 of the Municipality Council Pietrowice Wielkie from 23 April 2009 about local development plan in developing sides of Pietrowice Wielkie.

15. Kessel - catalogue.Access 20 May2017 http://www.kessel.pl/aktualnosci/informacjearchiwalne-2009/przydomowa-oczyszczalnia-sciekow-inno-clean.html

16. Z. Domaczewski. Operator's guide for wastewater treatment plant. Polskie Zrzeszenie Inżynierów i Techników Sanitarnych, Poznań (2011)

17. Ordinance of the Head of the Municipality Pietrowice Wielkie no OP/PBOŚ/7010/1/2012 (2014) 
18. Regulation (PL) no 1800/2014 of the Minister of Environment on the conditions to be met when discharging sewage into water or soil, and on the substances particularly harmful to the aquatic environment. Official Journal No 1800, Warsaw (2014)

19. Watersupply and wastewater system.(in Polish) No 2/132 (2015)

20. Letter from Environmental Ministry of Poland No DGO.pz-022-21/28/451/10 with the guidelines for sludge (2010)

21. H. Kulikowska. Practical aspects of sewerage sludge managment from domestic treatment plant. Water supply and Wastewater treatment Company in Lublin (2015)

22. J. Boguniewicz-Zablocka, I.Klosok-Bazan, V. Naddeo. DOI 10.1007/s11356-0170608-8 Environ Sci Pollut Res 24,32 (2017)

23. Watersupply and wastewater system.(in Polish) No 10/140 (2015) 